\section{Academy on the move Munich}

Officials at the 'Academy of Science and Technology in Berlin' have begun reluctantly to consider moving the academy out of West Berlin. Berlin's new mayor, Walter Momper (Social Democrat), declared in his inaugural speech on 13 April that the academy would be closed "as soon as possible". The academy, a favoured project of the previous Christian Democratic city government, was founded in 1987 as an interdisciplinary think-tank concentrating on technology and society. Academy spokesman Eberhard Vogt said the academy has had offers from three other Länder in West Germany but that remaining in Berlin is a "priority".

Several major science organizations in West Germany, including the science advisory council Wissenschaftsrat, the Deutsche Forschungsgemeinschaft and the Max Planck Society, criticized Momper's plan to close the academy as "a politically motivated exertion of influence".

S.D.

\section{Independent students}

\section{London}

Hungary's first independent students' organization, the Students' Chamber, was established at the end of last month in the faculty of economics of the Pannonius University of Pecs. The chamber, set up following the voluntary dissolution of the faculty committee of the Communist Youth Union (KISZ), is essentially non-political and "free of ideologies". The purpose of the chamber, the founding document says, is the representation and protection of students' interests. The only political question on which the students' chamber will take a stance, it says, are those directly connected with higher education.

V.R.

\section{Call for papers}

\section{Sydney}

Two University of Queensland reports agree that there is a correlation between the number of publications a scientist produces and the chance of obtaining funds.

Anthony Wheeler, a senior tutor in the Department of Pharmacology and Physiology, claims that scientists are forced to boost the numbers of their publications as competition heightens for declining budgets. But increases in numbers, Wheeler writes, are often produced by publishing the same material repeatedly, the division of one set of results to produce as many separate short publications as editors will bear (referred to as 'salami science') and increasing the numbers of co-authors on each paper.

Peter Sheehan, the university's Pro-Vice Chancellor of Research, has looked at indicators of research performance and finds that "the number of papers published did relate closely to the amount of money and grants given".

T.E.

\title{
Human rights assessed
}

\section{London}

MANDATORY testing for human immunodeficiency virus (HIV) or the compulsory registration of suspected HIV carriers could lead to prosecution under international human rights law, according to a report published recently by the British Medical Association.

The report, written by Paul Sieghart, a lawyer specializing in human rights, examines the legitimacy, in terms of the international law of human rights, of the policies which governments might adopt in order to limit the spread of AIDS.

Under the European Convention on Human Rights, interference with the privacy of an individual is acceptable only if it is "necessary in a democratic society for the protection of health". Sieghart says that because a positive AIDS test "will be perceived as an effective death warrant", and because mandatory HIV screening is not perceived by public health experts as an effective means of reducing the spread of infection, the severe adverse consequences of mandatory screening outweigh any benefits and such a scheme would not be justifiable under international human rights law.

Disclosure of the result of an HIV test to a third person without consent would be unjustifiable, says Sieghart, except if a patient refuses to take the necessary precautions not to pass on the infection to a known sexual partner, for example. Disclosure to another health worker is not justifiable on the grounds that he or she is at risk, says Sieghart, because health workers should be trained in procedures needed to protect themselves.

Compulsory registration of suspected HIV carriers and the mandatory collection of identifiable personal information about AIDS sufferers or HIV carriers, without protection of that information by strict rules of confidentiality, would also be unjustifiable interference with privacy. But making it a criminal offence for an HIV carrier knowingly or recklessly to infect others might be justifiable on public health grounds.

Sieghart also says that estimating the prevalence of HIV infection by testing samples taken with the patients' consent, for other purposes, would not interfere with the right to privacy if the samples cannot be traced to the individuals from whom they were taken.

On no grounds would the prohibition of marriage for persons known to be HIVpositive or the compulsory testing for HIV of people who want to marry be justified. Neither would mandatory abortions or sterilizations for HIV-infected women, because this would be a violation of the human right to found a family.

The right to work is protected by international human rights law, so an applicant for a job could not be legitimately refused employment or be dismissed on the grounds that that person was HIV-positive, unless the absence of infection was a necessary occupational qualification or the infection would clearly and substantially affect job performance.

Christine McGourty

\section{ANTARCTIC TREATY}

\section{Convention hits more trouble}

\section{Paris \& Sydney}

IN a television interview last week, French Prime Minister Michel Rocard made a surprise declaration that France is not prepared to ratify a convention supplementing the Antarctic Treaty to limit mineral exploration in the Antarctic. "The convention improves the situation slightly", he said, but added that discussions should seek to go further.

The convention, which is the third major amendment to the 1959 Treaty, was initiated by New Zealand and was adopted in June last year. Of the seven nations that have territorial claims to Antarctica, France and Australia have still not ratified the convention.

The convention requires all mineral exploration projects to be submitted for international scrutiny and seeks to close a loophole through which signatory nations could carry out illicit operations through companies owned by non-signatories. Until the convention comes into force, signatories further undertake to halt all mineral exploration. Although France has denied that it has plans to exploit Antarctic mineral wealth, Rocard's «non» will inevitably add grist to the mill of the environmental action group, Greenpeace. Over the past few years, Greenpeace has drawn attention to environmental damage allegedly being caused by the construction of a French landing-strip, accusing France of opening the way for mineral exploration under the guise of scientific research.

Australia last week put off its decision on the treaty. The minister for the environment, Senator Graham Richardson, wants Australia to sign, arguing that it is better to have an agreement that permits exploration rather than risk uncontrolled development. "Mineral developments, if they are to begin in any unplanned way, could lead to disaster", Senator Richardson said. With France's refusal it seems likely that negotiations will have to begin again in Wellington. Peter Coles \& Tania Ewing 